\title{
Investigating Iranian English Learners' Private Speech Across Proficiency Levels and Gender Based on Vygotsky's Sociocultural Theory
}

\author{
Mahan Yaghoubi ${ }^{1}$ Parisa Farrokh ${ }^{2}$
}

Accepted: 8 January 2022 / Published online: 20 January 2022

(C) The Author(s), under exclusive licence to Springer Science+Business Media, LLC, part of Springer Nature 2022

\begin{abstract}
This study was an attempt to investigate Iranian EFL learners' private speech across proficiency levels and gender while doing reading comprehension tasks. Moreover, it was an attempt to examine the different forms of private speech produced by Iranian English learners. Six forms of private speech were coded and analyzed: affective markers, sub-vocalization, switch from L2 to L1, repetition, unfinished sentences, and self-directed questions. It was a descriptive correlational research. The participants of this study were ninety female and male EFL learners at three levels of foreign language proficiency from two schools in Lahijan, Iran. They were selected from 110 students by administering an Oxford Quick Placement Test. Next, reading comprehension tests were administered to the participants. In order to gather data, each participant was equipped with a MP3 voice recorder to keep track of very low private speech markers while performing reading tasks. Pearson ChiSquare test was utilized to determine the probable relationship between the six forms of private speech and learners' proficiency levels and gender. The results revealed that there was statistically significant relationship between the forms of private speech produced by Iranian EFL learners and their foreign language proficiency. However, the outcomes did not yield a significant correlation regarding gender and the forms of private speech. It can be concluded that private speech is responsible for both regulating mental ability in complex tasks and facilitating internalization of mental ability. In second /foreign language learning, externalized private speech functions not just as a self-regulatory mechanism aiding problem-solving but as a tool in learning and internalizing the L2.
\end{abstract}

Keywords Iranian EFL learners · Language learning strategies · Private speech · Sociocultural theory $\cdot$ Zone of proximal development

\section{Abbreviations}

\section{L1 First language}

Parisa Farrokh

farrokh_p@yahoo.com

1 Department of English Language Translation, Lahijan Branch, Islamic Azad University, Lahijan, Iran

2 Department of English Language Translation, Lahijan Branch, Islamic Azad University, Lahijan, Iran 


$\begin{array}{ll}\text { L2 } & \text { Second language } \\ \text { S/F } & \text { Second/foreign } \\ \text { SCT } & \text { Sociocultural theory } \\ \text { EFL } & \text { English as a foreign language } \\ \text { AMs/Fs } & \text { Affective markers/fillers } \\ \text { SV } & \text { Sub-vocalization form } \\ \text { S L2 to L1 } & \text { Switch from L2 to L1 } \\ \text { R } & \text { Repetition } \\ \text { US } & \text { Unfinished sentences } \\ \text { SDQ } & \text { Self-directed questions } \\ \text { PS } & \text { Private speech } \\ \text { ZPD } & \text { Zone of proximal development }\end{array}$

\section{Introduction}

Sociocultural theory (SCT) stresses the interaction between developing people and the culture in which they live. Sociocultural theory implies that human learning is mainly a social process. To develop a link between the cognitive and the social perspectives, which can result in successful learning, mediation through developmentally collaborative dialogue in the learner's Zone of Proximal Development (ZPD) is inevitable (Swain, 2000). Vygotsky (1978) believed that ZPD is ''the distance between the actual developmental level as determined by independent problem solving and the level of potential development as determined through problem solving under guidance or in collaboration with more capable peers" (p. 86).

According to sociocultural theory, cognitive development is essentially a socially mediated process, in which the mediational connection between the social and mental ability is created and, in large part, by language, as it develops from social speech to private speech, which in turn into inner speech. The study of private speech and its importance in language learning has been a rather controversial area in linguistics and psychology. The majority of the probes have proved that private speech is more important in the process of learning a language (McCafferty, 2004; Donato, 2000; Ohta, 1995; Frawley, 1992; Buckwalter, 2001). Private speech is the use of language for self-regulation of behavior. It is agreed upon by many researchers that learners may use private speech as a tool to guide behavior and to solve problems (Fernyhough, 1992; Kozuli, 2003; Ohta, 2001; Rogoff, 1990; Russell, 1997). In this way, private speech is of interest to educators and the phenomenon of private speech raises many questions regarding ways, if any, to encourage and assist learners, especially those with special needs, to self-regulate, self-monitor and solve problems.

This study aims to examine the relationship between the forms of private speech produced by Iranian EFL learners in reading tasks, across their proficiency levels and gender. It is also worth mentioning that not enough studies have been conducted regarding the study of private speech with respect both gender and different proficiency levels which can also be considered as a problem or a new opportunity for exploring a new area or a field in applied linguistics. Since, the study of private speech in L2 learning has encompassed a number of other dimensions including cross-cultural differences in the use of private speech, an exploration of the degree to which internalization of a second language can occur, the importance of applying L1 forms of private speech in collaborative problem-solving activities, the role of private speech in language play, the gestures that 
accompany private speech and what they convey, the forms and functions of private writing, and facilitating the use of private speech in language class (McCafferty, 2004). As a result, this research provides mediational spaces for reading skill, scaffold instruction during the comprehension process, and creating opportunities for self-talk to promote EFL students' self -regulation while reading. Accordingly, in terms of sociocultural theory, the critical importance of mediating space during reading activity is presented in this probe. In this respect, reading which was regarded as a solely individualistic skill in the past has been looked from a completely different viewpoint now. According to Remi and Lawrence (2012) reading is a social skill which requires learners to actively participate and interact with the task. Thus, the outcomes of this study can be helpful pedagogically through suggesting new techniques and methods of teaching reading skill to the English learners. To satisfy the target of the investigation, the following research questions are proposed: (1) Is there any statistically significant relationship between the forms of private speech produced by Iranian EFL learners and proficiency levels (low- intermediate- high)? (2) Is there any statistically significant relationship between the forms of private speech produced by Iranian EFL learners and gender? Based on the above mentioned questions, the following null hypotheses were raised:

1. There is not any statistically significant relationship between the forms of private speech produced by Iranian EFL learners and proficiency levels (low- intermediate- high).

2. There is not any statistically significant relationship between the forms of private speech produced by Iranian EFL learners and gender.

\section{Review of Literature}

\section{Sociocultural Theory}

Sociocultural theory proposes that almost all mental functions of humans originate in the social and cultural context and language is like a tool for mediating our mental functioning (Vygotsky, 1978). Sociocultural theory (SCT) holds that cognitive development is mediated socially and in large part the language acts as mediation between the social and mental worlds (DiCamilla \& Anton, 2004). One of the central concepts to sociocultural theory refers to internalization (Gass \& Selinker, 2008). The process of internalization allows for moving the relationship between an individual and his or her environment to later performance. It was argued by Gass and Selinker (2008) that one way which internalization occurs, "is through imitation, known as private speech, which can be both immediate and intentional and delayed" (p. 284). Besides, based on the studies conducted in the realm of child development, internalization of L2 features is done through imitation, but this imitation is a significant, intentional and potentially transformative process than a mere rote mimicking (Cardenas Carlos, 2008). Vygotsky's sociocultural theory has been discussed in relation to four aspects of human cognitive development, namely mind, tools, Zone of Proximal Development (ZPD) and community of practice (Alsoraihi, 2019; Nuthall, 1997; Wertsch, 1985). First, mind extends beyond a person and people. Mind, according to Vygotsky is socially distributed. Thus our mental habits and functioning are dependent upon our interaction and communication with others, which are also affected by our 
environment, context, and history (Alsoraihi, 2019). The sociocultural perspective assumes that human cognition is formed through engagement in social activities (ibid).

The second aspect of cognitive development is tools. Tools assist the developing communicative and cognitive functions in moving from the social plane to the psychological one. Such tools include language; various systems of counting; algebraic symbol systems; works of art; writing; diagrams, maps and mechanical drawings and so on (Nuthall, 1997). The third aspect of cognitive development, ZPD (the Zone of Proximal Development) was defined by Vygotsky (1978) as "the distance between the actual developmental level as determined by independent problem solving and the level of potential development as determined through problem solving under adult guidance or in collaboration with more capable peers" (p. 86). The fourth aspect of cognitive development is community of practice, "where learning a subject domain is viewed as a process of becoming a member of a community of practice" (Mason, 2007, p. 340). A 'community of practice' is a group of people who are recognized as having a special expertise in some area of significant cultural practice (ibid).

Lantolf and Thorne (2006) contended that the principles of the SCT can also be used to explain Second Language Acquisition (SLA). Sociocultural theory implies that learning takes place in a social environment and considers learners as active constructors of their own learning environments (Johnson, 2006; Mitchel \& Myles, 2004). Lightbown and Spada (2006) believed that individuals can achieve higher levels of knowledge functioning through social interactions. In other words, sociocultural theory claims that without social interaction with other more knowledgeable peers, cognitive development will not occur. Mediation and scaffolding are essential for cognitive development to take place (Lantolf \& Thorne, 2006). According to SCT, individuals utilize language as a mediating tool to regulate mental process (Daniels, 2011). Therefore, language plays an important role in facilitating L2 development through its role as a symbolic tool of the mind. In fact, language as a sign of higher mental functioning within the individual's community of practice emerges first as social speech with the main function of regulating and controlling interaction with other participants, and then transforms into inner speech, i.e., thought (ibid).

When applied to an L2 classroom setting, the principal factor is exposing the learners to the required ZPD, the distance between the actual, individual development, and the level of potential development by resorting to the determining and enabling processes known as assisted performance or scaffolding (Tharp \& Gallimore, 1991). Ohta (2001) implies that in order to achieve successful language learning collaboration alone is not enough. The zone of proximal development (ZPD) emphasizes on the need to accomplish something beyond the current level of development as a necessary ingredient. Along with collaboration, a developmentally appropriate challenge is required to stimulate development in the ZPD. Language acquisition is regarded as a process of internalizing social interaction and this process includes being able to regulate interactions in L2 along with utilizing L2 as a tool for thinking. The ZPD is one of the main concepts in sociocultural theory that indicates the significant role that teachers have as mediators (Clark \& Graves, 2005; Lantolf \& Thorne, 2006).

Describing SCT, in higher mental activity, can be a kind of mediation which exists and what mediates the mind is the social activity (Carney et al., 2015). In other words, this theory asserts that social activities organize endowed capabilities like language and enable individuals to consciously control mental activities like planning and problem solving. Moreover, SCT contends that within the process of language acquisition, an individual's external speech is gradually internalized and combined with thought through communicative activities. Internalization is in fact the process through which cultural artifacts take on a 
psychological function moving from interpsychological (between people) into the intrapsychological (within the individual) planes through mechanisms such as imitation. The final results of second language acquisition are that people are able to think about things through the target language and then language and thought are combined together to become verbal thought. The developing steps can be named as external speech (speech without thought), private speech i.e., speech beginning to combine with thought and directed to the self), and inner speech. i.e., speech which has become verbal thought (ibid). Cook (2008) also believed that second language learning is embedded within social events and it happens as an individual interacts with people, objects, and events in the environment.

\section{Private Speech}

Private speech (PS) is social in genesis and may, hence, be social or communicative in its appearance, but it is nonetheless psychological in terms of function (Berducci, 2004). In fact, private speech is speech which is directed towards the self for the aim of organizing and directing one's or more specifically a language learner's mental activity. Furthermore, private speech is the speech self, used to control the self, while making its attempt to perform the task alone (ibid). Thus private speech originates in external speech 'as the voice of a teacher, caretaker, parents, and so on during some type of training” (p. 332). He also stated that private speech comprises both an internal and external form.

According to DiCamilla and Anton (2004) sociocultural theory makes two important claims regarding the phenomenon of private speech. First, although private speech is often social and communicative in appearance, it is psychological in function, which means that private speech is directed by the self as the speaker to the self as a listener. In the early stages of child development, they argued that private speech functions more in naming and describing specific aspects of children's actions and their environment than with planning and directing actions, and as children mature, "private speech takes on planning, directive, and evaluative function, and tends to precede and follow actions rather than co-occur with them" (p. 39).

Second, private speech is more abbreviated than social speech. The major distinguishing feature of inner speech is dearth of psychological subject and existence of psychological predicates. It was explained by DiCamilla and Anton (2004) that "the psychological subject has to deal with what an utterance is about and what is already in the mind of listener, while psychological predicate is new, what is said about the (psychological) subject" (p. 39). The study of private speech and its importance in language learning has been a rather controversial area in linguistics and psychology.

Researchers have reported mixed findings regarding the phenomenon of private speech. A substantial amount of these researches have been put into investigating the relationship between private speech and language proficiency. The majority of these probes have proved that private speech is rather important in the process of learning a language. It can also be interpreted from several studies that L1 plays a vital role in L2 acquisition since some students prefer to shift from L2 to L1 in difficult situations. Under the influence of Vygotskian approaches to Frawley and Lantolf (1985) were the first scholars who focused on investigating the role of private speech in second language learning. They studied the private speech production of second language learners performing picture narration tasks. Frawley and Lantolf (1985) reported that at lower levels of proficiency, L2 learners tend to use private speech more often than in the higher levels. However, they argued that private speech is most likely context-bound, so it is possible 
that even a native-like L2 learner might need to use private speech in some situations. They also came to the conclusion that there is no point in which learners' use of private speech ends and no one can be completely self-regulated in all situations and also due to low level of proficiency in L2, learners tend to use their L1 when they are in a difficult situation. Villamil and de Guerrero (1996) did a study of peer review sessions in an ESL writing course. They found private speech emerges as a mediating strategy that facilitates the revision process. These researchers identified two main purposes in their students' use of private speech. One was to guide their own behavior by means of repetitions, selfaddressed questions and self-reminders. The other was to release affective load.

Centeno-Cortes and Jiménez Jiménez (2004) carried out a research to see the role of private speech in Spanish learners. They came to the conclusion that "L1 private verbal thinking plays a crucial role in the case of L2 speakers engaged in problem-solving, and therefore it should be recognized as very important point in the process of learning" (p. 31). They also found that learners used both L1 and L2 private speech and more proficient learners used more private speech than the less proficient ones. They emphasized the emergence and mediational function of private speech in second language learning contexts.

In the Japanese EFL context, Ohta (2001) in her study examined the patterns of private speech of Japanese second language learners at a university classroom. She reported the students' repetition, linguistic manipulation and vicarious response as forms of private speech in her data. Ohta argued that the use of private speech is a part of the internalization process when learners attempt to use the social interactive resources of the L2. In another study conducted by Storch and Aldosari (2010) the effect of learner proficiency pairing and task type on the amount of L1 used by learners of English as a foreign language (EFL) during pair work was investigated. The participants were asked to perform three tasks with different focus and familiarity: jigsaw (meaning-focused), composition (familiar task) and text-editing (focus on grammatical accuracy). They found that the use of L1 during pair work activity was very low and compared to the proficiency pairing, the task type had more effect on the amount of L1 use. The learners used L1 to manage the task and to search for vocabulary. When the students thought about the vocabulary, they used L1 in private speech; they appeared to use the L1 to confirm the meaning of some words in their own minds.

Bahrami (2001) examined the use of private speech as the mental rehearsal among different language proficiency levels in the Iranian EFL context. The participants were 128 junior and 48 senior female university students of English Translation. They were divided into three proficiency groups of high, intermediate and low, based on their TOEFL scores. The students were asked to answer a 40-item questionnaire. The result showed that almost all of the learners confirmed that they experienced private speech in English. Furthermore a significant relationship was found between proficiency and private speech.In this relation, Shigematsu's (2010) also conducted a research on the concept of private speech and its development among L2 learners. Shigematsu described private speech as the conscious 'use of the L2 for thinking as a way of helping one mediating the ways of the L2 and culture' (2010, p. 2). Self-reports from five L2 learners of English and Japanese revealed that private speech tends to develop with increased proficiency and exposure to naturalistic L2 settings.

In a study, Kato (2009) focused on the role of private speech in reading L2 texts. Data was collected from 64 L1 Japanese (ESL) participants. The results revealed that, when the ability to use private speech was suppressed, reading comprehension was impacted negatively. The effect was greater among learners with lower reading proficiency levels, 
suggesting that less proficient readers rely more on private speech during reading than advanced readers.

Rahimi and Tahmasbi (2010) studied the private speech and collaborative interaction among 54 EFL freshmen students during a reading course. For the control group, the teacher paraphrased and discussed the reading; the learners in the experimental group were asked to perform different tasks including paraphrasing, summarizing, discussing collaboratively and use private speech. The sessions were video-recorded. The final test of comprehension and oral presentation were the two measurements used in this study. The performance of learners was analyzed based on accuracy, complexity, and fluency. It was revealed that scaffolding and private speech helped the learners be successful and accurate in task completion.

In a research done by Anani Sarab and Gordani (2014), the patterns of private speech of Iranian EFL learners were probed while solving some riddles in L2 individually. They found that private speech has with it such beneficial functions as planning, managing the thought, self-orientation, motivation, and controlling anxiety. Similarly, Ebadi (2014) studied the role of L2 private speech on online dynamic assessment of two Iranian university students residing in UK and France along with two English native speakers. The results revealed that L1 emerged in the private speech of L2 learners when they encountered challenging task of decreasing the gaps in L2 knowledge. He emphasized the use of L1 as a mediating tool for meaningful L2 processing. According to Abdikhah and Khorshidi (2013) both beginner and advanced EFL learners employed private speech during completing a task. They also noted that compared to advanced learners who mainly externalized their private speech in English, beginners used Persian. The results also indicated that there was not a significant relationship between the amount of private speech produced and success of task completion.

In a recent study done by Gheisari (2017), resurfacing of private speech markers by Iranian elementary female EFL learners in teacher-learner interaction was investigated. To this end 12 female learners and a same-sex teacher were selected as the participants of the study. As for the data, six 30-min reading comprehension tasks with the interval of every two weeks were recorded and analyzed. A high number of literal translation, metalanguage, and switching to L1 mid-utterance were reported, however, the generated number of such private markers as self-directed questions, reading aloud, reviewing, and self-explanations in L2 was comparatively less which could be due to low L2 proficiency of the learners. In addition, the findings of the study highlighted the importance of paying more attention to private speech as a mediating tool in cognitive regulation of learners in doing L2 tasks.

Although many researches have been done on private speech in individual task completion, there is no research has been done to investigate the patterns of private speech produced by Iranian English learners while performing reading comprehension tasks with respect to gender and proficiency level differences.

\section{Method}

The present study employed a descriptive correlational design. An Oxford Quick Placement Test (OQPT) as the homogenizing tool was utilized. It was administered to 110 EFL learners. The data for the study consisted of 15 sessions of audio recording data of private speech produced by the learners while doing reading tasks. The reading tasks included five reading comprehension texts 
with multiple choice questions to elicit learners' private speech. The test was utilized to measure the reading comprehension knowledge of the learners. No changes or modifications were made to the test. Both quantitative and qualitative data were used in this research.

\section{Participants}

For present study, 45 male and 45 female students from two schools, with different proficiency levels were selected based on their performance OQPT. Learners whose scores were in the range of 18-27 were chosen as elementary, 37-47 as intermediate, and more than 47 , as advanced. Their age ranged from 12 to 16 . Private speech produced by the students in reading tasks, were recorded, transcribed and then analyzed. The participants were native speakers of Persian who had learned English solely in the educational settings of the EFL context of Iran, with no experience of living or studying in any English speaking country.

\section{Instruments}

An Oxford Quick Placement Test was administered to 110 EFL learners from two schools to select a homogeneous sample. Cronbach's Alpha for OQPT was $(\alpha$ OPT $=0.76)$. Once the participants were selected, 5 reading comprehension tests were used to elicit learners' private speech. Tests were taken from British Council site https://learnenglish.britishcouncil.org/ skills/reading/ According to the learners' proficiency levels, appropriate tests were selected. The reliability of the tests for different proficiency levels were calculated as $0.737,0.709,0.71$ respectively.

\section{Data Collection Procedure}

The study took place in the academic year 2020-2021. To select the participants, an OQPT was administered to 110 male and female students from two schools. Due to global pandemic of Covid-19, the test was administered via Google link. Among 110 students, 90 male and female EFL learners were chosen on the basis of OQPT scores (18-27 as elementary, 37-47 as intermediate, more than 47 as advanced). Each level consisted 15 male and 15 female students. Next, reading comprehension tests were administered to the participants. The purpose of the survey was to discover the relationship between private speech forms and EFL learners' proficiency levels and gender. In doing so, the students were requested to read the texts carefully and answer the questions. Each participant was also equipped with a MP3 voice recorder so that low volume sounds generated were also kept while performing reading tasks. The main data was extracted, transcribed and analyzed from MP3 recordings. Due to Coronavirus outbreak, the researcher had to obey Covid-19 protocols, therefore, he asked 3 students to present each session and recorded their private speech while they were doing reading tasks. As the result the number of sessions increased to 15 . Twenty minutes of each session were recorded to extract and analyzed learners' private speech. 


\section{Results}

The results reported here take into account the forms of private speech produced by ninety female and male Iranian EFL learners while doing reading tasks at three levels of foreign language proficiency. The data were analyzed using the Statistical Package for the Social Sciences (SPSS, Version 25). Descriptive statistics were run and the sums of frequencies for different forms of private speech were computed. In order to provide answer to the research questions, Pearson Chi-Square test was utilized to determine the probable relationship between the six forms of private speech and learners' proficiency levels and gender. The six forms of private speech were (1) Affective markers/fillers, (2) Sub-vocalization form, (3) Switch from L2 to L1, (4) Repetition, (5) Unfinished sentences, and (6) Selfdirected questions. The first categorical data was level of proficiency that included three categories (i.e., beginner, intermediate, and advanced). The second categorical data was gender with two levels (i.e., female and male). There was also one scale data that was the frequency of private speech. Therefore, the non-parametric Pearson Chi-square test fit the data best. Pearson Chi-square test is used to analyze the relationship between categorical by interval data (Gravetter \& Wallnau, 2004). The direction and the strength of the relationship for the interval by nominal data were measured using Eta statistic. It is worth mentioning that the analysis was performed at $p=0.05$ level of significance. Besides, since the non-parametric test was run, the normal distribution of the data did not matter. The results of the statistical analyses are given in the following sections.

\section{Results of the Frequency Analyses}

\section{Frequency Analyses for the Private Speech Used across 3 Levels of Proficiency}

First, frequency analyses were made for the EFL learners' uses of private speech across 3 levels of foreign language proficiency. The results are given in Table 1.

The frequency table revealed that advanced EFL learners used higher private speech $\left(f_{P S}=288\right)$ than intermediate $\left(f_{P S}=263\right)$ and beginners $\left(f_{P S}=158\right)$. In addition, there was

Table 1 Frequency analyses for the private speech used by EFL leaners at 3 levels of foreign language proficiency

\begin{tabular}{|c|c|c|c|c|c|c|c|}
\hline Proficiency level & $\mathrm{AMs} / \mathrm{Fs}$ & Sv & SL2 to L1 & $\mathrm{R}$ & US & SDQ & Total PS \\
\hline \multicolumn{8}{|l|}{ Advanced } \\
\hline $\mathrm{N}$ & 30 & 30 & 30 & 30 & 30 & 30 & 30 \\
\hline Sum & 101 & 64 & 32 & 35 & 30 & 26 & 288 \\
\hline \multicolumn{8}{|l|}{ Intermediate } \\
\hline $\mathrm{N}$ & 30 & 30 & 30 & 30 & 30 & 30 & 30 \\
\hline Sum & 106 & 80 & 7 & 62 & 4 & 4 & 263 \\
\hline \multicolumn{8}{|l|}{ Beginner } \\
\hline$N$ & 30 & 30 & 30 & 30 & 30 & 30 & 30 \\
\hline Sum & 69 & 46 & 6 & 21 & 7 & 9 & 158 \\
\hline
\end{tabular}

$A M s / F s$ affective markers/fillers, $S V$ sub-vocalization form, $S L 2$ to $L 1$ switch from L2 to L1, $R$ repetition, $U S$ unfinished sentences, $S D Q$ self-directed questions, $P S$ private speech 
a slight difference between advanced $\left(\mathrm{f}_{\mathrm{AMs} / \mathrm{Fs}}=101\right)$ and intermediate $\left(\mathrm{f}_{\mathrm{AMs} / \mathrm{Fs}}=106\right) \mathrm{EFL}$ learners in terms of using "Affective markers/fillers." When it comes to "Sub-vocalization form," intermediate EFL learners $\left(f_{S V}=80\right)$ employed more Sub-vocalization form than advanced $\left(f_{S V}=64\right)$ or beginners $\left(f_{S V}=46\right)$. "Switch from L2 to L1" was frequently used by advanced learners $\left(\mathrm{F}_{\mathrm{SL} 2 \mathrm{toL} 1}=32\right)$. In contrast, intermediate $\left(\mathrm{f}_{\mathrm{SL} 2 \mathrm{toL} 1}=7\right)$ and beginner learners $\left(f_{S L 2 t o L 1}=6\right)$ reflected very low level of this form of private speech. Moreover, intermediate learners $\left(f_{R}=62\right)$ employed "Repetition" private speech nearly twice more than the advanced learners $\left(f_{R}=35\right)$ and almost three times more than beginner learners $\left(f_{R}=21\right)$. It appeared that advanced learners $\left(f_{U S}=30\right)$ tended to use "Unfinished sentences" far more than the intermediate $\left(\mathrm{f}_{\mathrm{US}}=4\right)$ and beginner learners $\left(\mathrm{f}_{\mathrm{US}}=7\right)$. Finally, "Self-directed questions" were commonly used by advanced learners $\left(f_{\mathrm{SDQ}}=26\right)$ rather than intermediate $\left(f_{\mathrm{SDQ}}=4\right)$ or beginner learners $\left(\mathrm{f}_{\mathrm{SDQ}}=9\right)$. Figure 1 displays the frequency of six forms of private speech used by EFL learners at three different levels of foreign language proficiency.

As it was shown in Fig. 1, there were some differences among advanced, intermediate, and beginner EFL learners in terms of their use of private speech.

\section{Frequency Analyses for the Private Speeches Used Across Gender}

Next, frequency analyses were made for the EFL learners' uses of private speech across gender. The results are given in Table 2 .

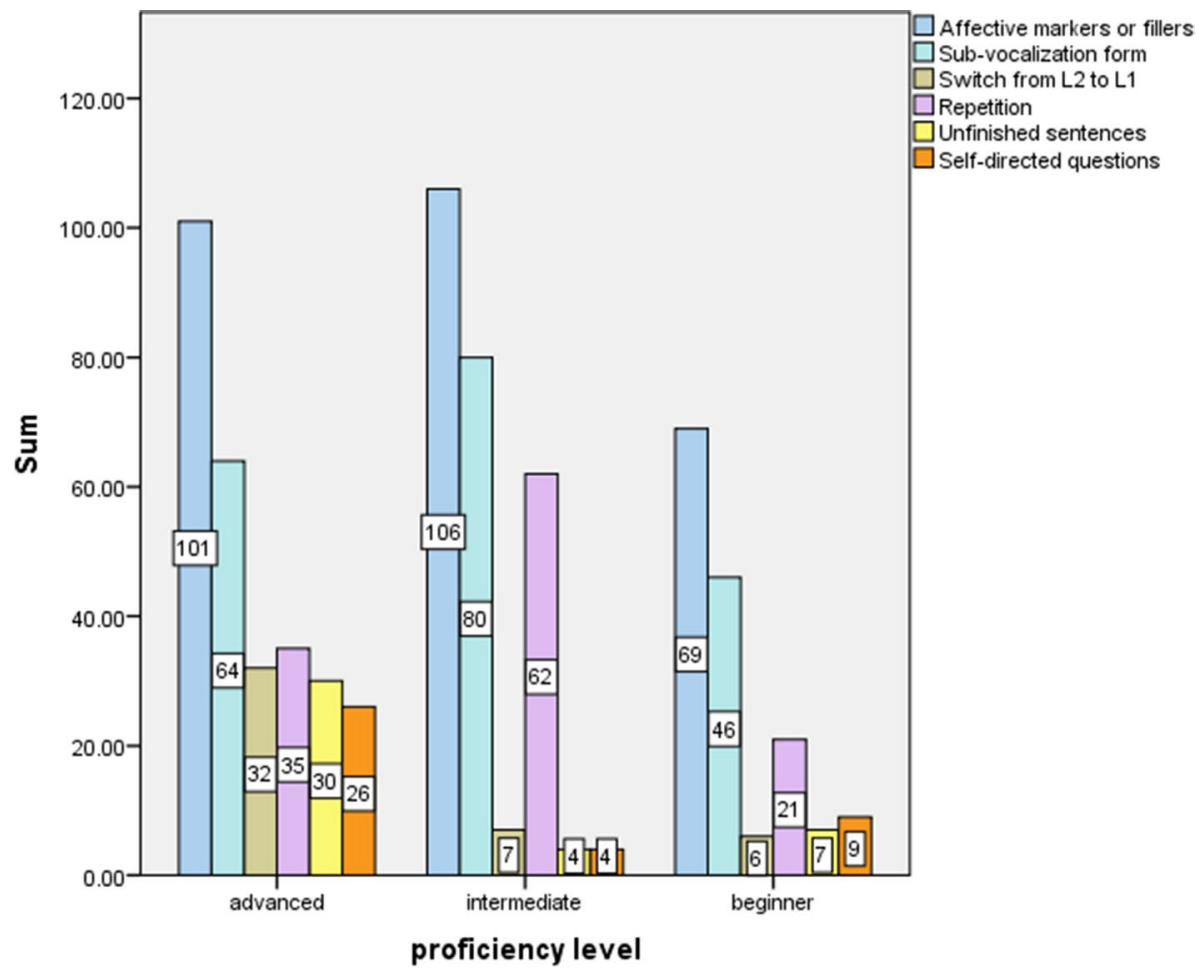

Fig. 1 Six forms of private speech used by EFL learners across different levels of proficiency 
Table 2 Frequency analyses for the private speech used by EFL leaners across gender

\begin{tabular}{llllllll}
\hline Gender & AMs/Fs & Sv & SL2 to L1 & R & US & SDQ & Total PS \\
\hline Female & & & & & & & \\
$\mathrm{N}$ & 45 & 45 & 45 & 45 & 45 & 45 & 45 \\
Sum & 145.00 & 98.00 & 36.00 & 53.00 & 27.00 & 22.00 & 381.00 \\
Male & & & & & & & \\
$\mathrm{N}$ & 45 & 45 & 45 & 45 & 45 & 45 & 45 \\
Sum & 131.00 & 92.00 & 9.00 & 65.00 & 14.00 & 17.00 & 328.00 \\
\hline
\end{tabular}

$A M s / F s$ affective markers/fillers, $S V$ sub-vocalization form, $S$ L2 to $L 1$ switch from L2 to L1, $R$ repetition, $U S$ unfinished sentences, $S D Q$ self-directed questions, $P S$ private speech

The results of the frequency analyses indicated that female EFL learners $\left(f_{\text {female } P S}=381\right)$ used more private speech than male participants $\left(f_{\text {male }}\right.$ PS $\left.=328\right)$. However, male participants $\left(f_{R}=65\right)$ used "Repetition" more than female participants $\left(\mathrm{f}_{\mathrm{R}}=53\right)$ did. In addition, "Affective markers/fillers" were the most frequently used form of private speech by both female and male participants. Overall, the results revealed that apparently different forms of private speech were not used equally across gender. Figure 2 displays the frequency of six forms of private speech used by EFL learners across gender.

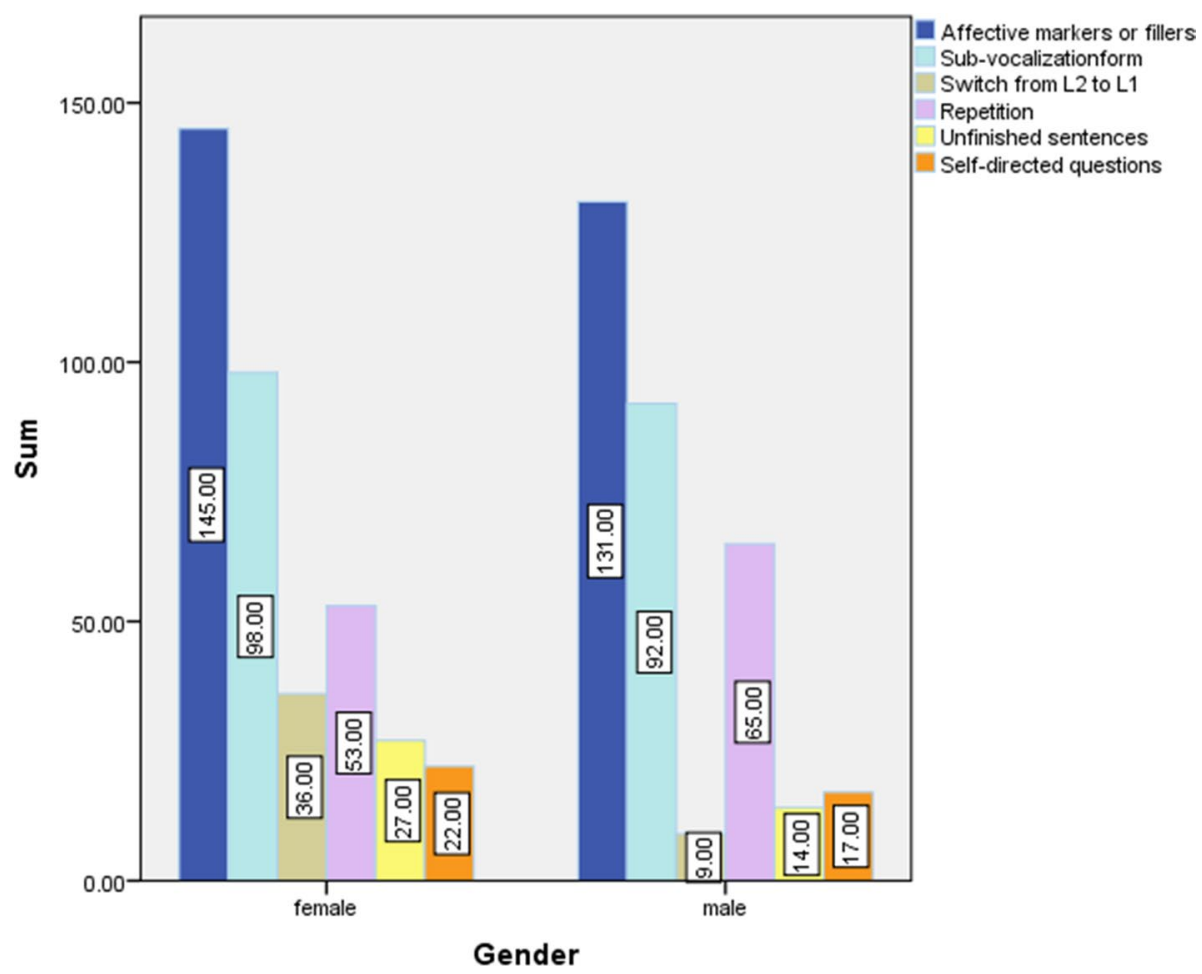

Fig. 2 Six forms of private speech used by EFL learners across gender 
According to the results of this study, females showed stronger preference towards using private speech compared to males.

\section{Forms of Private Speech Used Across Gender and Proficiency Levels}

Frequency analyses were also made for the EFL learners' uses of private speech across gender and proficiency level. The results are given in Table 3.

Based on the results, advanced female participants used the highest number of private speech $\left(f_{\mathrm{PS}}=178\right)$. In contrast, beginner male participants utilized the lowest number of private speech $\left(f_{P S}=70\right)$. With respect to different forms of private speech, intermediate female participants reported the least number of "Self-directed questions" $\left(f_{\mathrm{SDQ}}=1\right)$. On the other hand, advanced female participants and intermediate male participants used

Table 3 Frequency analyses for the private speech used by EFL leaners across gender and proficiency levels

\begin{tabular}{|c|c|c|c|c|}
\hline \multirow[t]{2}{*}{ Proficiency level } & \multicolumn{2}{|l|}{ Valid N } & \multicolumn{2}{|l|}{ Sum } \\
\hline & Female & Male & Female & Male \\
\hline \multicolumn{5}{|c|}{ Affective markers/fillers } \\
\hline Advanced & 15 & 15 & 61.00 & 40.00 \\
\hline Intermediate & 15 & 15 & 45.00 & 61.00 \\
\hline Beginner & 15 & 15 & 39.00 & 30.00 \\
\hline \multicolumn{5}{|c|}{ Sub-vocalization form } \\
\hline Advanced & 15 & 15 & 37.00 & 27.00 \\
\hline Intermediate & 15 & 15 & 33.00 & 47.00 \\
\hline Beginner & 15 & 15 & 28.00 & 18.00 \\
\hline \multicolumn{5}{|l|}{ Switch from L to L1 } \\
\hline Advanced & 15 & 15 & 27.00 & 5.00 \\
\hline Intermediate & 15 & 15 & 5.00 & 2.00 \\
\hline Beginner & 15 & 15 & 4.00 & 2.00 \\
\hline \multicolumn{5}{|l|}{ Repetition } \\
\hline Advanced & 15 & 15 & 15.00 & 20.00 \\
\hline Intermediate & 15 & 15 & 29.00 & 33.00 \\
\hline Beginner & 15 & 15 & 9.00 & 12.00 \\
\hline \multicolumn{5}{|c|}{ Unfinished sentences } \\
\hline Advanced & 15 & 15 & 22.00 & 8.00 \\
\hline Intermediate & 15 & 15 & 2.00 & 2.00 \\
\hline Beginner & 15 & 15 & 3.00 & 4.00 \\
\hline \multicolumn{5}{|c|}{ Self-directed questions } \\
\hline Advanced & 15 & 15 & 16.00 & 10.00 \\
\hline Intermediate & 15 & 15 & 1.00 & 3.00 \\
\hline Beginner & 15 & 15 & 5.00 & 4.00 \\
\hline \multicolumn{5}{|c|}{ Total private speech } \\
\hline Advanced & 15 & 15 & 178.00 & 110.00 \\
\hline Intermediate & 15 & 15 & 115.00 & 148.00 \\
\hline Beginner & 15 & 15 & 88.00 & 70.00 \\
\hline
\end{tabular}


the highest number of "Affective markers/fillers" ( $f=61)$. Figure 3 displays the sum of private speech used by EFL learners across gender and proficiency level.

\section{Results of Inferential Statistics}

To see if the difference between the private speech used by the female and male EFL learners at three levels of proficiency levels was statistically significant, Chi-square test was performed. In other words, Chi-Square Test was launched to explore the differences among the female and male EFL learners at beginner, intermediate, and advanced levels concerning their use of private speech (Table 4).

The two-sided asymptotic significance of the Chi-square statistic for the relationship between language proficiency level and total private speech was lower than the significance value of 0.05 . Generally, it could be concluded that the relationship between these two variables was statistically significant. This implied that the participants at specific level of language proficiency used different degrees of private speech $\left(\chi^{2}\right.$ Proficiency Level* ${ }^{*}$ Total PS $=62.592, p \leq 0.05$ ).

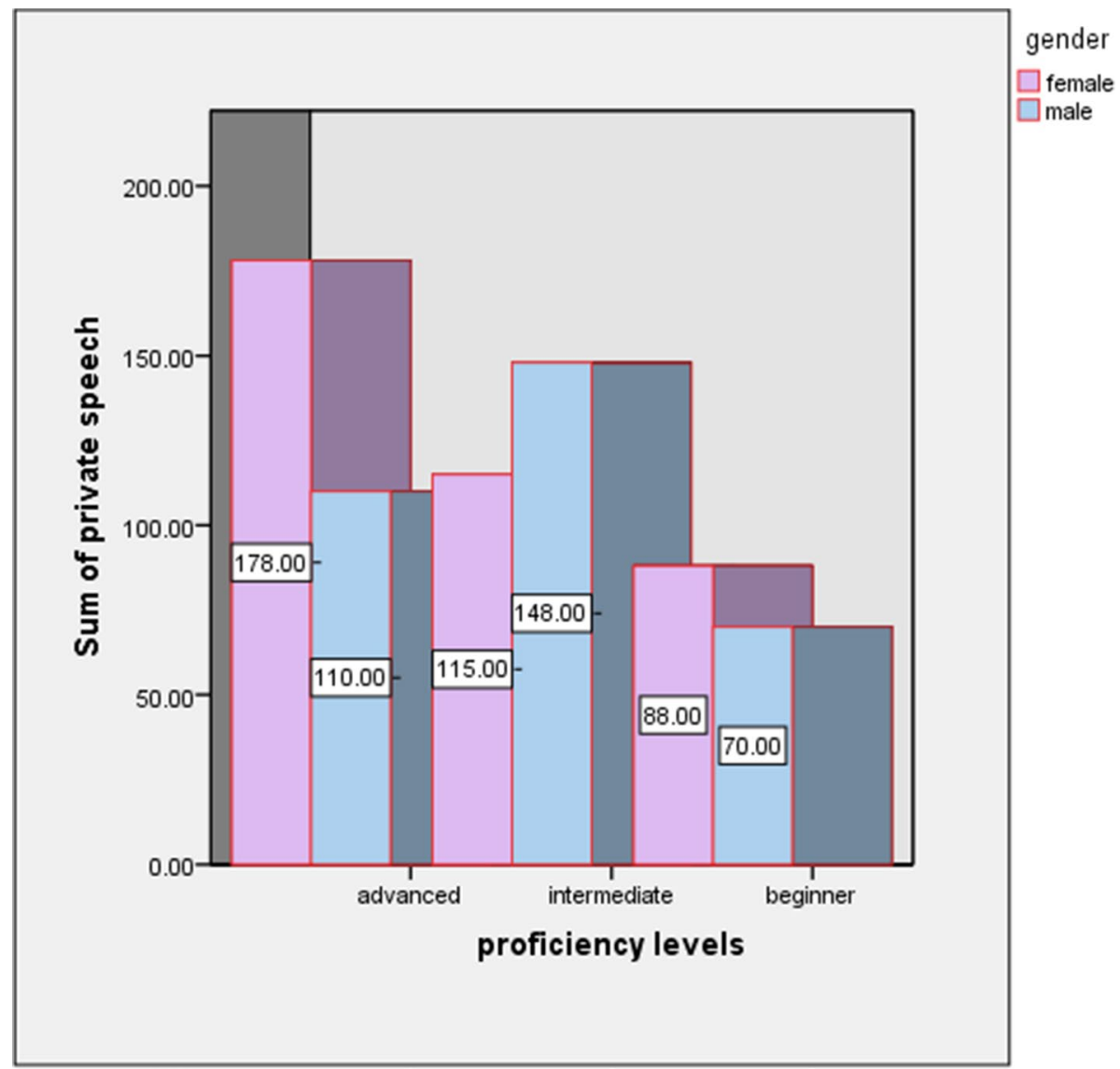

Fig. 3 Total private speech used by EFL learners across gender and proficiency level 
Table 4 Chi-square test

\begin{tabular}{llll}
\hline Variables & $\begin{array}{l}\text { Pearson Chi-square } \\
\text { value }\end{array}$ & $d f$ & $\begin{array}{l}\text { Asymp. } \\
\text { Sig. } \\
(2 \text {-sided) }\end{array}$ \\
\hline Proficiency level * total PS & & 34 & .002 \\
Gender * total PS & 62.592 & 17 & .222 \\
Proficiency level * affective markers/fillers & 21.102 & 14 & .113 \\
Proficiency level * sub-vocalization form & 20.564 & 14 & .078 \\
Proficiency level * switch from L2 to L1 & 22.032 & 12 & .149 \\
Proficiency level * repetition & 17.006 & 10 & .003 \\
Proficiency level * unfinished sentences & 26.606 & 8 & .017 \\
proficiency level* self-directed questions & 18.604 & 8 & .025 \\
Gender * affective markers/fillers & 17.514 & 7 & .798 \\
Gender * sub-vocalization form & 3.840 & 7 & .296 \\
Gender * switch from L2 to L1 & 8.434 & 6 & .326 \\
Gender * repetition & 6.941 & 5 & .686 \\
Gender * unfinished sentences & 3.091 & 4 & .309 \\
Gender * Self-directed questions & 4.792 & 4 & .713 \\
\hline
\end{tabular}

The second Chi-square test was run to examine the possible relationship between gender and total private speech. The results indicated that there was no statistically significant association between gender and use of private speech $\left(\chi^{2}\right.$ Gender* Total PS $=21.102$, $p \geq 0.05$ ).

The Chi-square tests for the proficiency level and "Affective markers/ fillers" $\left(\chi^{2}\right.$ Proficiency Level* $\mathrm{AMs} / \mathrm{Fs}=20.564, p \geq 0.05$ ), the proficiency level and "Sub-vocalization form" $\left(\chi^{2}\right.$ Proficiency Level* SVF $\left.=22.032, p \geq 0.05\right)$, and the proficiency level and "Switch from L2 to L1" ( $\chi^{2}$ Proficiency Level* SLL2toL1 $\left.=17.006, p \geq 0.05\right)$ were not statistically significant. This implied that level of language proficiency did not affect the use of these three forms of private speech. In other words, beginner, intermediate, and advanced learners used the same amount of "Affective markers/ fillers," "Sub-vocalization," and "Switch from L2 to L1 form" regardless of their level of proficiency they belonged to. However, the significant values of Pearson Chi-square test for the proficiency level and "Repetition" $\left(\chi^{2}\right.$ Proficiency Level $* \mathrm{R}=26.606, p \leq 0.05)$, proficiency level and "Unfinished sentences" $\left(\chi^{2}\right.$ Proficiency Level* US $=18.604, p \leq 0.05)$, and proficiency level and "Self-directed questions" $\left(\chi^{2}\right.$ Proficiency Level $* \mathrm{SDQ}=17.514, p \leq 0.05)$ showed statistically significant relationship between learners' uses of these three forms of private speech and their levels of language proficiency. In other words, the results of the Chi-square tests confirmed significant relationships simply between three forms of private speech and the learners' proficiency level.

Nevertheless, none of the forms of private speech yielded significant results across gender. Meaning that gender factor did not affect the use of different forms of private speech. In other words, female and male participants used the same private speech regardless of their gender.

The strength and direction of the relationship between the variables were examined by running Eta test, the results of which are presented in the following table: 
Table 5 Results of eta test

\begin{tabular}{llc}
\hline Variables & Dependent & Eta value \\
\hline Proficiency level * total PS & Total PS dependent & .450 \\
Gender * total PS & Total PS dependent & .141 \\
Proficiency level * affective markers/fillers & Affective markers/fillers dependent & .344 \\
Proficiency level * sub-vocalization form & Sub-vocalization form dependent & .323 \\
Proficiency level * switch from L2 to L1 & Switch from L2 to L1 dependent & .279 \\
Proficiency level * repetition & Repetition dependent & .506 \\
Proficiency level * unfinished sentences & Unfinished sentences dependent & .438 \\
Proficiency level * self-directed questions & Self-directed questions dependent & .391 \\
Gender * affective markers/ fillers & Affective markers/fillers dependent & .098 \\
Gender * sub-vocalization form & Sub-vocalization form dependent & .047 \\
Gender * switch from L2 to L1 & Switch from L2 to L1 dependent & .208 \\
Gender * repetition & Repetition dependent & .119 \\
Gender * unfinished sentences & Unfinished sentences dependent & .163 \\
Gender * self-directed questions & Self-directed questions dependent & .069 \\
\hline
\end{tabular}

Table 6 Guidelines for interpreting (r) value ( Adopted from Salkind, 2010)

\begin{tabular}{ll}
\hline r values & Interpretation \\
\hline 0.8 & 1.0 very strong relationship \\
0.6 & 0.79 strong relationship \\
0.4 & 0.59 moderate relationship \\
0.2 & 0.39 weak relationship \\
0.0 & 0.19 very weak or no relationship \\
\hline
\end{tabular}

Table 5 shows the results of Eta test that was run to determine the strength and the direction of the relationship between the variables. Salkind's (2010, p. 129) guideline was used for interpreting the (r) values. The guideline is presented in Table 6.

Based on the guidelines proposed by Salkind (2010), the proficiency level and total private speech had "moderate" relationship $(\mathrm{r}=0.450)$. Moreover, there were "moderate" relationship between proficiency level and "Repetition" ( $\mathrm{r}=0.506)$ as well as proficiency level and "unfinished sentences" $(\mathrm{r}=0.438)$. The relationships between proficiency level and Self-directed questions $(r=0.391)$, proficiency level and Affective markers/ fillers $(\mathrm{r}=0.344)$, proficiency level and Sub-vocalization form (0.323), and proficiency level and Switch from L2 to L1 ( $r=0.279)$ were "weak." In addition, the relationship between gender and all six forms of private speech were very weak and not statistically significant.

\section{Discussion}

This study was conducted to examine the possible correlation between Iranian EFL learners' forms of private speech, their proficiency levels and gender. This research also investigated the different forms of private speech markers produced by beginner, intermediate and advanced Iranian EFL learners while they focused on reading tasks. The results of 
Pearson revealed that there was statistically significant relationship between the forms of private speech produced by Iranian EFL learners and their foreign language proficiency levels $\left(\chi^{2}\right.$ Proficiency Level* Total PS $\left.=62.592, p \leq 0.05\right)$. Consequently the first null hypothesis was rejected. However, the results did not yield a significant correlation regarding gender

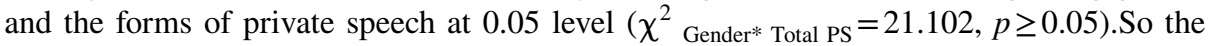
hypothesis regarding existence of no relationship between the forms of private speech produced by Iranian EFL learners and gender was retained. As it was already stated, private speech is a vital gateway to understanding how language intermediates and directs thought processes (Lantolf et al., 2015). In terms of learning English, private speech either with the help of the first language or with the help of the target language facilitates interaction with the second language in relation to the needs of personal learning, for example, doing reading tasks (Lee, 2008). Overall the current study showed the emergence of private speech produced by EFL learners while attempting to perform the task alone, thus it can be concluded that private speech can act like a mediating tool in cognitive regulation of learners while doing the tasks in L2. This is in line with findings of many previous studies such as Gheisari(2017), Anani Sarab and Gordani (2014), Rahimi and Tahmasbi (2010), Ebadi (2014), Khorshidi and Abdikhah (2013), Lantolf and Frawley (1985), Storch and Aldosari (2010), Ohta (2001) and Berducci (2004).

According to the frequency of private speech produced in different levels, (Table 1), it was cleared that advanced EFL learners used higher private speech $\left(f_{P S}=288\right)$ than intermediate $\left(f_{P S}=263\right)$ and beginners $\left(f_{P S}=158\right)$. The finding is congruent with the studies done by Vilamil and De Guerrero (1996) and Centeno-Cortes and Jiménez Jiménez (2004) who also found that the private speech increased significantly with the increase in proficiency. However, this outcome contradicts Kato's report (2009), in which it was cleared that less proficient readers rely more on private speech during reading than advanced readers. Moreover, the results of the present study indicated that switch from L2 to L1 was frequently used by advanced learners $\left(\mathrm{F}_{\mathrm{SL} 2 \mathrm{toL} 1}=32\right)$. In contrast, intermediate $\left(\mathrm{f}_{\mathrm{L} 2 \mathrm{toL} 1}=7\right)$ and beginner learners $\left(\mathrm{f}_{\mathrm{SL} 2 \mathrm{toL} 1}=6\right)$ reflected very low level of this from of private speech which is opposite to Frawley and Lantolf's (1985), Storch and Aldosari's (2010), Abdikhah and Khorshidi's, (2013), Ebadi's (2014) and Gheisari's (2017) studies since they reported the high frequency of switching from L2 to L1 in low proficient level learners, because these learners had not yet had L2 as a cognitive tool, thereby resorted to L1 private speech markers in most cases. On the whole the outcomes of the current research demonstrated that all beginner, intermediate and advanced learners apparently used both L1 and L2 in their private speech. Contrary to McCafferty's (2004) study, in which it was claimed that in S/F language learning settings, private speech emerges only in L2 and not in L1. Furthermore, it should be mentioned the results of the frequency analyses indicated that female EFL learners (ffemale PS $=381$ ) used more private speech than male participants (f male $\mathrm{PS}=328$ ). However, male participants ( $\mathrm{R}=65$ ) used "repetition" more than female participants (f $\mathrm{R}=53$ ) did. In addition, "affective markers/fillers" were the most frequently used form of private speech by both female and male participants. Affective markers are utterances that served a motivational purpose, or that showed relief, exhaustion, and discovery of an idea or solution. They were found to help learners control frustration and anxiety and help attention focusing (Centeno-Cortes \& Jimenez, 2004; DiCamilla \& Anton, 2004). According to Anani Sarab and Gordani (2014) using fillers can give learners some time in order to think about the next action to do. The recurring affective markers/fillers in this study were: "cool", "oh", "aww/oww", "oh my God", "yeah", "wow", "hmmm" and "uh huh". 
The private speech statements have the function of creating joint perception of the language activity and one another. These statement make it possible for learners to get and deliver regulation in different stages of cognitive development. Learners express their understanding concerning themselves and peers in a classroom context in their efforts to form shared cognition assuming expert and novice roles. Comments on self also helps them have ideas about their language skills and knowledge which in turn helps them reach the intersubjective state. According to the SCT, interaction need not be solely two-way in nature (Lantolf \&Throne, 2006). In other, words, students are sometimes involved in selftalk which helps them infer meaning and comprehend best. In these phases participants illuminate their thought developments through private speech that is used for regulation purposes. As a result of studies of private speech, a more complex structure of dialogic communication in dyadic conversations emerges. Dialogic communication may not consist of only other-directed utterances between the interlocutors. It also consists of self-directed utterances, even during those moments when the interlocutors seem to be communicating with each other. Hence, the use of private speech in principle cuts across any native/nonnative speaker dichotomy.

\section{Implications of the Study}

There are some pedagogical implications regarding the current research. Private speech is talking to oneself in order to express the actions required to successfully achieve task completion; this form of self-mediation guides the person to carry out an activity, which is above their current competence. The mediation exists in higher mental activities and what mediates the mind is the social activity. To put it differently, this theory asserts that social activities organize endowed capabilities like language and enable individuals to consciously control mental activities such as planning and problem solving (Donato, 2000; Ellis, 2003; Lantolf \& Thorne, 2006; Ohta, 2001). Thus, the main function of private speech is its mediating function as a tool in the process of learning, teachers need not be worried about the language learners' incomplete or incomprehensible utterances as they are striving to internalize their present thinking, as a result, errors are not seen in terms of any deviations from native- speaker norm, but different cognitive functions (Anani Sarab \& Gordani, 2014).

Moreover, according to SCT, overt private speech, which occurs among L2 learners, is a reflection of the L2 internalization process, representing an early stage in the development of L2, which can be helpful for L2 researchers, psycholinguists and psychologists while studying S/F language learning process. As the findings of the present study revealed, a lot of L1 private speech markers might occur during the task activities which are cognitively challenging for L2 learners, therefore, despite the common policy of "no L1 use in L2 classes" which is strictly followed by many Iranian EFL teachers (Gheisari, 2017, p. 74), use of related-to-L1 private speech markers should be embraced. Based on the outcomes of many studies related to PS, it can be implied that not only PS behaviors have an internalizing role, but also helping learners in their appropriation of the L2 and in the formation of an internal psychological plane mediated by the L2. Therefore, by paying attention to learners' PS, teachers may help learners who express negative emotions cope better when performing cognitively frustrating or difficult tasks. Finally, it is recommended that teachers pay close attention to learners' production of private speech across different tasks, proficiency levels and gender, acknowledge it, and certainly not inhibit it. 


\section{Limitations of the Study}

Several limitations were in the present study that may affect on the results. As it was already mentioned, a small size of population was considered in this study. So the generalizability of findings must be treated more cautiously. To find the adequate numbers of students adapting to the levels of the research seemed to be hard due to global pandemic of Covid-19. Another limitation of the present study was the age of the participants that ranged from 12 to 16 . So the results cannot be generalized to other learners with other ranges of age. The time span in this study (15 sessions and 20 min recorded speech) is not enough. A long-term study may come to more reliable results. Moreover, the present study is limited to classification, type and frequency of different private speech markers while doing reading tasks, and happened in interaction between teacher and learner, since it was impossible to clarify private speech in learner- learner interactions because of Coronavirus outbreak.

\section{Suggestions for Further Research}

Several suggestions for further research on PS arise from this research. To further estimate the accuracy of all the results presented in this study, future research should focus more on number of students from both genders and different proficiency levels for clarification, description and frequency of PS. In addition, more research is needed to be conducted on the issue in different settings both with teachers-learners and learner-learner with different characteristics from that of those in the present study. Also, since the study was conducted on the analysis of PS produced by Iranian EFL learners while doing reading tasks, doing more research on different types of linguistic genre, skills and translation is also recommended. In addition, further studies can examine various age groups. Moreover, along with studies on different forms of PS, it is suggested that research related to the properties of contents and functions of PS should be carried out with more diverse populations than has been the case up to now. Little is known, for example, on the PS of non- English students /learners.

\section{Conclusion}

Private speech is responsible for both regulating mental ability in complex tasks and facilitating internalization of mental ability. In second /foreign language learning, externalized private speech functions not just as a self-regulatory mechanism aiding problem-solving but as a tool in learning and internalizing the L2. In addition, when the learners want to take control over a cognitive task, they resort to themselves internally and recur their thought in the different forms of private speech to overcome difficulties.

Acknowledgements The authors would like to thank the students for their contribution in this study.

Authors' Contribution This work was carried out in collaboration between the two authors. Author PF supervised the work, decided upon and provided the sources, performed the statistical analyses, revised and edited the drafts. Author MY collected the data and wrote the drafts of the manuscript, and implemented the revisions. Both authors read and approved the final manuscript. 
Funding There is no funding.

Availability of Data and Material The datasets analyzed in the current study are available from the corresponding author upon reasonable request.

\section{Declarations}

Conflict of interest There are no conflicts of interest.

\section{References}

Abdikhah, S., \& Khorshidi, F. (2013). An investigation of the private speech phenomenon in the collaborative interaction of Iranian adult EFL learners. 3L: the Southeast Asian Journal of English Language Studies, 19(3), 71-85.

Alsoraihi, M. H. (2019). Bridging the gap between discourse analysis and classroom practice. English Language Teaching, 12(8), 79-88. https://doi.org/10.5539/elt.v12n8p79

Anani Sarab, M. R., \& Gordani, Y. (2014). The role of L2 private speech in cognitive regulation of adult Foreign Language learners. Journal of English Language Teaching and Research, 14, 1-18.

Bahrami, A. (2001). Inner speech as mental rehearsal: The case of EFL Learners. Unpublished MA thesis. Iran University of Science and Technology.

Berducci, D. F. (2004). Vygotsky through Wittgenstein: A New perspective on Vygotsky's developmental continuum. Theory and Psychology, 14(3), 329-353. https://doi.org/10.1177/0959354304043639

Buckwalter, P. (2001). Repair sequences in Spanish L2 dyadic discourse: A descriptive study. The Modern Language Journal, 85(3), 380-397. https://doi.org/10.1111/0026-7902.00115

Cardenas Carlos, M. S. (2008). Psycholinguistic and sociocultural approaches to second language learning: A never ending debate. Theoretical Discussion Papers, 10, 142-154.

Carney, N. J., Lantolf, P., \& Poehner, M. E. (2015). Sociocultural theory and the pedagogical imperative in L2 education: Vygotskian praxis and the research/practice divide. Applied Linguistics, 36(1), 143-146. https://doi.org/10.1093/applin/amu073

Centeno-Cortes, B., \& Jiménez Jiménez, A. (2004). Problem-solving tasks in a foreign language: The importance of the L1 in private verbal thinking. International Journal of Applied Linguistics, 14(1), 7-35. https://doi.org/10.1111/j.1473-4192.2004.00052.x

Clark, K. F., \& Graves, M. F. (2005). Scaffolding students' comprehension of text. The Reading Teacher, $58(6), 570-580$.

Cook, V. (2008). Second language learning and language teaching. Arnold.

Daniels, H. (2011). Vygotsky and psychology. In U. Goswami (Ed.), The Wiley-Blackwell handbook of childhood cognitive development (pp. 673-696). Wiley-Blackwell.

DiCamila, F. G., \& Anton, M. (2004). Private speech: A study of language for thought in the collaborative interaction of language learners. International Journal of Applied Linguistics, 14(1), 36-69. https:// doi.org/10.1111/j.1473-4192.2004.00053.x

Donato, R. (2000). Sociocultural contributions to understanding the foreign and second language classroom. In J. P. Lantolf (Ed.), Sociocultural theory and second language learning (pp. 27-52). Oxford University Press.

Ebadi, S. (2014). L2 private speech in online dynamic assessment: A sociocultural perspective. Iranian Journal of Applied Linguistics, 17(1), 49-70.

Ellis, R. (2003). Task-based language learning and teaching. Oxford University Press.

Feigenbaum, P. (1992). Development of the syntactic and discourse structures and discourse structures of private speech. In R. M. Diaz \& L. E. Berk (Eds.), Private speech: From social interaction to selfregulation (pp. 181-198). Elbraum.

Frawley, W. (1992). The cross linguistic study of private speech. In Paper presented at the first conference for socio-cultural research symposium on private speech and self-regulation, Madrid, Spain.

Frawley, W., \& Lantolf, J. P. (1985). Second language discourse: A Vygotskyan perspective. Applied Linguistics, 6(1), 19-44. https://doi.org/10.1093/applin/6.1.19

Gass, S. M., \& Selinker, L. (2008). Second language acquisition: An introductory course. New York: Lawrence Erlbaum Associates, Inc.

Gheisari, N. (2017). Private speech in teacher-learner interactions in an EFL context: A sociocultural perspective. Iranian Journal of Language Teaching Research, 5(2), 53-74. 
Gravetter, F. J., \& Wallnau, L. B. (2004). Statistics for the behavioral sciences (6th ed.). Wadsworth.

Johnson, K. E. (2006). The sociocultural turn and its challenges for second language teacher education. TESOL, 4O(1), 235-257. https://doi.org/10.2307/40264518Tesol

Kato, S. (2009). Suppressing inner speech in ESL reading: Implications for developmental changes in second language word recognition processes. The Modern Language Journal, 93(4), 471-488. https://doi. org/10.1111/j.1540-4781.2009.00926.x

Kozulin, A. (2003). Psychological Tools and Mediated Learning. In A. Kozulin, B. Gindis, V. S. Ageyev, \& S. M. Miller (Eds.), Vygotsky's educational theory in cultural context (pp. 15-38). Cambridge University Press.

Lantolf, J., \& Thorne, S. (2006). Sociocultural theory and second language acquisition. In B. van Patten \& J. Williams (Eds.), Theories in second language acquisition (pp. 201-224). Lawrence Erlbaum.

Lantolf, J., Thorne, S. L., \& Poehner, M. (2015). Sociocultural theory and second language development. In B. van Patten \& J. Williams (Eds.), Theories in second language acquisition (pp. 207-226). Routledge.

Lee, J. (2008). Gesture and private speech in second language acquisition. Studies in Second Language Acquisition, 30(2), 169-190. https://doi.org/10.1017/S0272263108080303

Lightbown, P. M., \& Spada, N. (2006). How languages are learned (3rd ed.). Oxford University Press.

Mason, M. (2007). Critical thinking and learning. Educational Philosophy and Theory, 39(4), 339-349. https://doi.org/10.1111/j.1469-5812.2007.00343.x

McCafferty, S. G. (2004). Space for cognition: Gesture and second language learning. International Journal of Applied Linguistics, 14(1), 1-6. https://doi.org/10.1111/j.1473-4192.2004.0057m.x

Mitchell, R., \& Myles, F. (2004). Second language learning theories (2nd ed.). Hodder Arnold.

Nuthall, G. (1997). Learning how to learn: The social construction of knowledge acquisition in the classroom. In Paper presented at the European Association for Research in Learning and Instruction (7th Biennial conference), Greece, Athens http://www.educ.canterbury.ac.nz/ultp.htm

Ohta, A. S. (1995). Applying sociocultural theory to an analysis of learner discourse: Learner-learner collaborative interaction in the zone of proximal development. Issues in Applied Linguistics, 6, 93-122. https://doi.org/10.5070/L462005219

Ohta, A. S. (2001). Second language acquisition processes in the classroom: Learning Japanese. Lawrence Erlbaum.

Rahimi, A., \& Tahmasbi, S. (2010). Mediating Iranian learners: private speech and scaffolding in reading comprehension. LIBRI: Linguistic and Literary Broad Research and Innovation, 1(2), 56-71.

Remi, A. V. C., \& Lawrence, W. (2012). Promoting sociolinguistic competence in the classroom proximal development. Language Teaching Research, 16(1), 36-90. https://doi.org/10.1177/1362168811423340

Rogoff, B. (1990). Apprenticeship in thinking: Cognitive development in social context. Oxford University Press.

Russell, J. (1997). How executive disorders can bring about an inadequate "theory of mind. In J. Russell (Ed.), Autism as an executive disorder (pp. 256-304). Oxford: Oxford University Press.

Salkind, N. J. (2010). Encyclopedia of research design (Vol. 1). California: Sage.

Shigematsu, B. K. (2010). Second language inner voice and identity. Ph.d. dissertation, University of Nevada.

Storch, N., \& Aldosari, A. (2010). Learners' use of first language (Arabic) in pair work in an EFL class. Language Teaching Research, 14(4), 355-375. https://doi.org/10.1177/1362168810375362

Swain, M. (2000). The output hypothesis and beyond: Mediating acquisition through collaborative dialogue. In J. Lantolf (Ed.), Sociocultural approaches to second language research (pp. 97-115). Oxford University Press.

Tharp, R. G., \& Gallimore, R. (1991). Rousing minds to life: Teaching, learning, and schooling in social context. Cambridge University Press.

Villamil, O., \& DeGuerrero, M. (1996). Peer revision in the L2 classroom: Social-cognitive activities, mediating strategies, and aspects of social behavior. Journal of Second Language Writing, 5(1), 51-75. https://doi.org/10.1016/S1060-3743(96)90015-6

Vygotsky, L. S. (1978). Mind in society: The development of higher psychological processes. Harvard University Press.

Wertsch, J. (1985). Vygotsky and the social formation of mind. MA Harvard University Press.

Publisher's Note Springer Nature remains neutral with regard to jurisdictional claims in published maps and institutional affiliations. 